\title{
A new species of Leiostracus from Bahia, Brazil (Gastropoda, Pulmonata, Orthalicidae)
}

\author{
Rodrigo B. Salvador ${ }^{1,2} \&$ Daniel C. Cavallari ${ }^{3}$
}

1. Staatliches Museum für Naturkunde Stuttgart, Rosenstein 1, 70191 Stuttgart, Germany.

2. Mathematisch-Naturwissenschaftliche Fakultät, Eberhard Karls Universität Tübingen, Hölderlinstraße, 12, 72074 Tübingen, Germany. (salvador.rodrigo.b@gmail.com)

3. Museu de Zoologia da Universidade de São Paulo, Av. Nazaré, 481, 04218-970 São Paulo, Brazil. (dccavallari@gmail.com)

\begin{abstract}
A remarkable new species of pulmonate snail was recently collected in a small Atlantic Rainforest fragment near the city of Canavieiras, state of Bahia, Brazil, an area known for a high diversity of land snails. It is described herein as Leiostracus fetidus sp. nov. and can be easily identified by its color pattern of irregular brown to black axial stripes on a white to yellow background, a reddish axial band "separating" the white peristome from the rest of the shell and a broad brown spiral band surrounding the umbilical region. Other diagnostic features include a relatively small size, a proto columellar fold and two very weak folds delimiting the basal region of the aperture. This discovery is a reminder of how little this fauna is known and also an alarm for proper conservation of these forest fragments.
\end{abstract}

KEYWORDS. Atlantic Rainforest, Bulimulinae, Canavieiras, Leiostracus fetidus sp. nov., Stylommatophora.

RESUMO. Uma nova espécie de Leiostracus da Bahia, Brasil (Gastropoda, Pulmonata, Orthalicidae). Uma nova espécie de gastrópode pulmonado foi recentemente coletada em um pequeno fragmento de Mata Atlântica nas vizinhanças de Canavieiras, Bahia, uma área de reconhecida diversidade de moluscos terrestres. Essa espécie é aqui descrita como Leiostracus fetidus sp. nov., podendo ser facilmente identificada pelo seu padrão de coloração composto por faixas axiais irregulares, de cor marrom a preto, uma faixa axial avermelhada "separando" o peristômio branco do restante da concha e uma faixa espiral marrom, larga e irregular, contornando a região umbilical. Outras características diagnósticas incluem um tamanho relativamente pequeno, uma proto-dobra columelar e duas leves dobras na região basal da abertura. A presente descoberta é um lembrete de quão pouco essa fauna é conhecida e também um alerta para a conservação desses fragmentos de mata.

PALAVRAS-CHAVE. Bulimulinae, Canavieiras, Leiostracus fetidus sp. nov., Mata Atlântica, Stylommatophora.

The original Brazilian Atlantic Rainforest has been fiercely exploited and degraded through the few centuries of the country's history. However, even the few remaining forest fragments still seem to hide new discoveries, especially of the scarcely studied land snail fauna (SimONE, 1999). The shell dealer José Coltro Jr. and his team recovered some fresh land snail shells in an Atlantic Forest fragment near the city of Canavieiras, state of Bahia, Brazil (Fig. 1). This material was donated to the Museu de Zoologia da Universidade de São Paulo (MZSP; São Paulo, Brazil) and the Staatliches Museum für Naturkunde Stuttgart (SMNS; Stuttgart, Germany), being described herein as Leiostracus fetidus sp. nov.

Leiostracus Albers, 1850 is an endemic South American genus that for a long time was considered a subgenus of Drymaeus Albers, 1850. It occurs in Guyana, Suriname and Brazil, being particularly diverse in the eastern and southeastern regions of the latter (BREURE, 1979; Simone, 2006). The genus is represented in Brazil by 15 species (Simone, 2006) and is characterized by its ovate-conical shell shape, a faint keel on the body whorl, the aperture shape and protoconch sculpture (see discussion below). The Brazilian species often show a color pattern consisting of brown and white bands (Simone, 2006; SALVADOR \& CAVALLARI, 2013b). For the anatomical characters of the genus (including radular), see Breure (1979).

\section{MATERIAL AND METHODS}

All material is housed in the malacological collections of the MZSP and SMNS, consisting of shells only (unfortunately, no living animal could be recovered). Shell measurements abbreviations used throughout the text: $\mathrm{H}$, shell length; $\mathrm{D}$, shell greatest width; $\mathrm{h}$, aperture height; $d$, aperture width.

Specimens of related species such as Leiostracus clouei (Pfeiffer, 1856), L. onager (Beck, 1837), L. subtuszonatus (Pilsbry, 1899) and L. vimineus (Moricand, 1833) were analyzed, stemming from the following collections: ANSP, Academy of Natural Sciences of Philadelphia (Philadelphia, USA); LMD, Löbbecke Museum Düsseldorf (Düsseldorf, Germany); MNHN, Muséum National d'Histoire Naturelle (Paris, France); MZSP; NHMUK, Natural History Museum (London, UK); SMF, Senckenberg Forschungninstitut und Naturmuseum Frankfurt (Frankfurt am Main, Germany); ZMA, Zoological Museum Amsterdam (Amsterdam, The Netherlands; now the NCB Naturalis); ZMB, Museum of Natural History, Humboldt University Berlin (Berlin, Germany; formerly Zoologisches Museum Berlin). The type material of the above- mentioned species were analyzed: MZSP 29794 (L. onager, neotype; Fig. 9); NHMUK 1975492 (L. clouei, lectotype; Fig. 11); SMF 302131 (L. vimineus, 
syntype); ZMB 10316 (L. vimineus, syntype).

\section{RESULTS}

\section{Leiostracus fetidus sp. nov.}

(Figs 2-8)

Type specimens. Holotype (MZSP 112123) and paratypes (13 specimens, MZSP 107577; 2 specimens, SMNS ZI0077108), Brazil, Bahia, Atlantic Rainforest fragment near the city of Canavieiras, $15^{\circ} 40^{\prime} \mathrm{S}, 39^{\circ} 02^{\prime} \mathrm{W}$, A. Bianchi col., vi.2012.

Etymology. From the Latin fetidus, meaning stinking. An ironic reference to the shells' stark smell of decomposing organic matter by the time we first examined them.

Distribution. Known only from type locality, an Atlantic Rainforest fragment near the city of Canavieiras, state of Bahia, Brazil (Fig. 1).

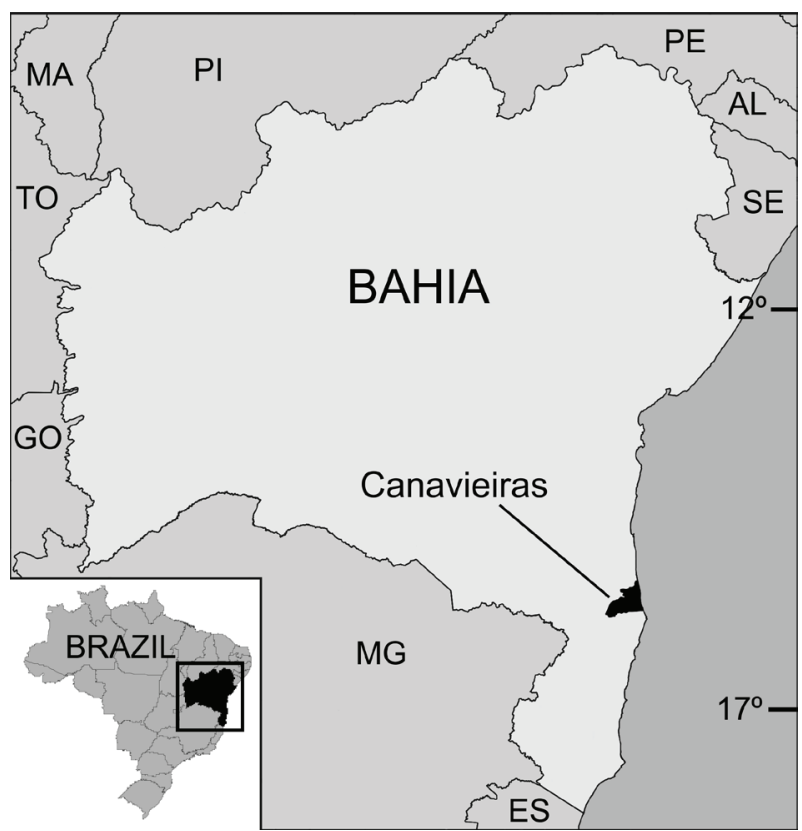

Fig. 1. Map showing the type locality of Leiostracus fetidus sp. nov., Canavieiras, state of Bahia, Brazil. Abbreviations of neighboring states: MA, Maranhão; PI, Piauí; PE, Pernambuco; AL, Alagoas; SE, Sergipe; TO, Tocantins; GO, Goiás; MG, Minas Gerais; ES, Espírito Santo.

Diagnosis. Shell somewhat small for genus. Color pattern composed of irregular brown to black axial stripes on pale beige to yellow background. Body whorl with broad brown spiral band with irregular contour surrounding umbilical region. Reddish axial band "separating" white peristome from remainder of shell. Reflected peristome on columellar region forms proto columellar fold. Aperture with two very weak folds delimiting basal region.

Description. Shell medium-sized (shell length $\sim 21$ $\mathrm{mm}$ ), ovate-conical; width $\sim 1 / 2$ shell length. Spire top color (first 2-4 whorls, including protoconch) light yellowish brown to pale beige, partially translucent; remaining whorls pale beige to yellow with irregular brown to black axial stripes; pattern interrupted on body whorl by broad brown spiral band with irregular contour surrounding umbilical region; axial stripes may diminish in quantity and width on body whorl region close to this spiral band. Reddish axial band "separating" white peristome from remainder of shell. Color pattern visible from inside of shell; region surrounding umbilicus white. Spire angle $\sim 50^{\circ}$. Protoconch ( $\sim 1 \frac{1}{2}$ whorls) sculptured by fine parallel axial wrinkles on topmost portion of whorls; this sculpture stops soon, being replaced by numerous very fine parallel spiral lines; transition to teleoconch unclear. Teleoconch smooth, except for growth lines. Whorls profile convex. Suture well-marked, deep, slightly oblique (diagonal) to columellar axis. Aperture large, oval, slightly prosocline $\left(\sim 20^{\circ}\right.$ with columellar axis), with two very weak folds delimiting basal region; $\sim 1 / 2$ shell length, $\sim 2 / 3$ shell width. Peristome reflected, especially on columellar region, partially covering umbilicus and forming a proto columellar fold. Body whorl $\sim 3 / 5$ shell length. Umbilicus narrow.

Measures (in mm). Holotype: 6 whorls; $\mathrm{H}=21.2$; $\mathrm{D}=11.7 ; \mathrm{h}=10.4 ; \mathrm{d}=7.8$. Mean $(\mathrm{n}=10): 6$ whorls; $\mathrm{H}$ $=21.0 \pm 0.9(\max 22.5 ; \min 20.1) ; \mathrm{D}=10.9 \pm 0.5(\max$ $11.7 ; \min 10.5) ; \mathrm{h}=9.4 \pm 0.5(\max 10.2 ; \min 8.7) ; \mathrm{d}=7.3$ $\pm 0.4(\max 7.8 ; \min 6.6)$.

\section{DISCUSSION}

Leiostracus fetidus sp. nov. can be readily identified by its relatively small size (similar species display a shell length of 25 to $30 \mathrm{~mm}$ ), color pattern and, especially, the red axial band preceding the peristome, a feature unknown in other Leiostracus species. Apart from this red axial band, the overall color pattern resembles other species from Bahia, namely Leiostracus onager (Fig. 9), L. subtuszonatus (Fig. 10) and even L. clouei (Fig. 11), especially in background color and the pattern of black to reddish brown axial stripes. Among these, L. fetidus sp. nov. is more alike to L. subtuszonatus (SALVADOR \& CAVALLARI, 2013b). The reddish brown band surrounding the umbilicus of $L$. fetidus sp. nov., however, has a more irregular contour when compared to L. subtuszonatus and L. clouei. Also, differently from L. subtuszonatus, in the new species there is not a clear spiral band devoid of axial stripes immediately after the brown axial band surrounding the umbilical region, but rather a subtle change in intensity, quantity and contour of axial and background coloration. The umbilicus' white to pale beige color is likewise similar to L. subtuszonatus. There is also some intraspecific variation in the color pattern of L. fetidus sp. nov. (Figs 7-8): specimens may present scarcer, more irregular, often interrupted axial stripes and/or a more evident, though not complete, diminishment of the axial coloration near the brown band surrounding the umbilical region (Fig. 8).

Regarding the shell shape and conchological features, one of the diagnostic characters of Leiostracus fetidus sp. nov. is the proto columellar fold in the aperture, which can also be seen in some other species of the genus (SimONE, 2006). Among these, the only one which more closely resembles L.fetidus sp. nov. is L. clouei (Fig. 11). 


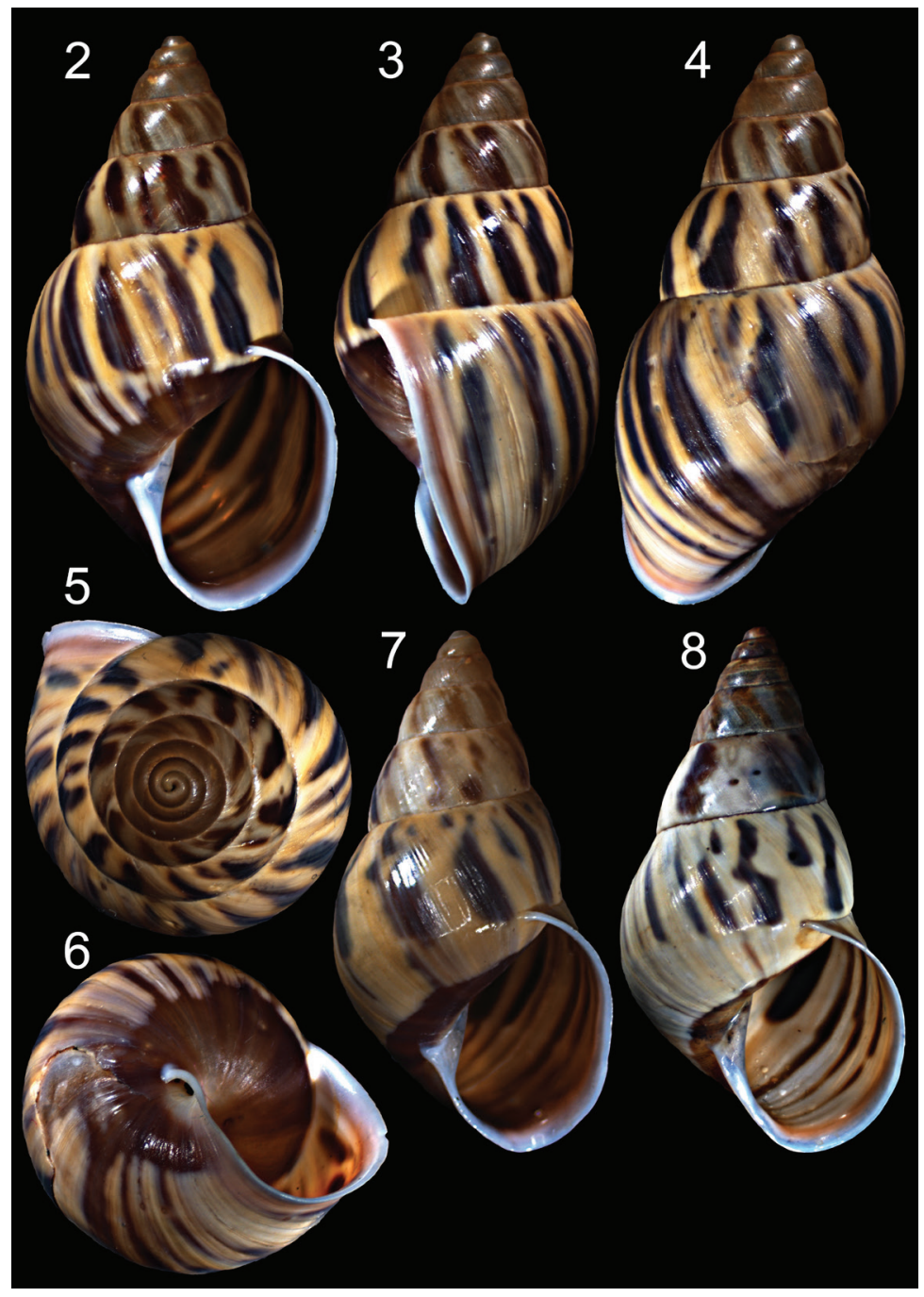

Figs 2-8. Leiostracus fetidus sp. nov.: 2-6, Holotype, MZSP 112123 (H=21.2 mm); 7, Paratype, MZSP 107577 (H=21.4 mm); 8, Paratype, MZSP $107577(\mathrm{H}=22.5 \mathrm{~mm})$.

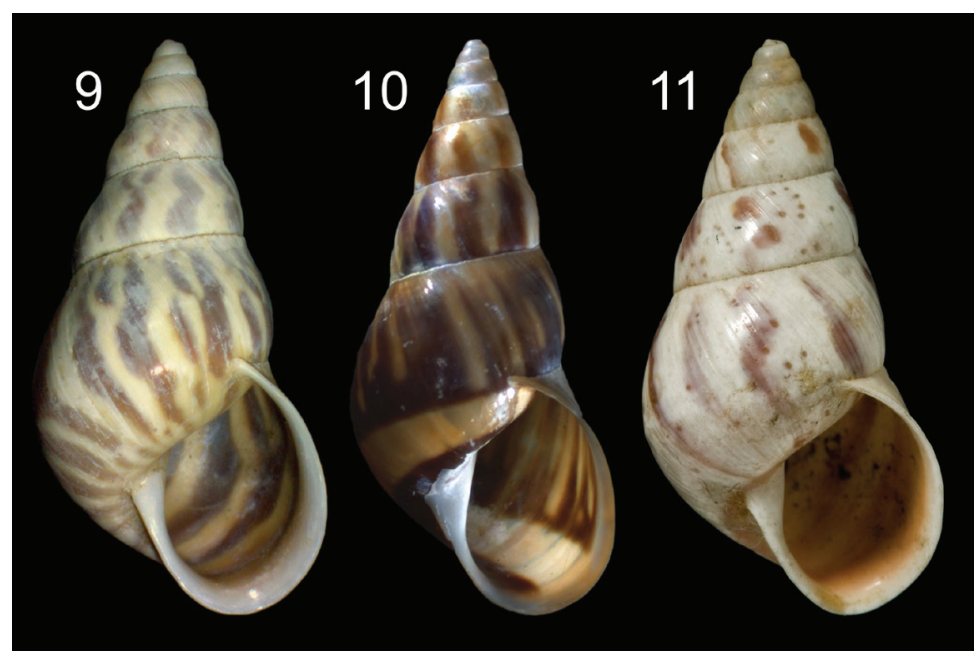

Figs 9-11. 9, Leiostracus onager (Beck, 1837), neotype (MZSP 29794; H = $25.5 \mathrm{~mm}, \mathrm{D}=12 \mathrm{~mm}$ ); 10, Leiostracus subtuszonatus (Pilsbry, 1899) (MZSP 108040; H = $28.5 \mathrm{~mm}, \mathrm{D}=13 \mathrm{~mm}$ ); 11, Leiostracus clouei (Pfeiffer, 1856), lectotype (NHMUK 1975491; H=22 mm, D = $11 \mathrm{~mm}$ ). 
Nevertheless, the new species can easily be distinguished from $L$. clouei by a broader shell, more convex whorls, larger body whorl and aperture, less prosocline aperture and the basal folds on the aperture (see below).

Another diagnostic feature of Leiostracus fetidus sp. nov. is the weak folds that delimit the aperture's basal region. Such folds are also known in L. vimineus, but in this species they are much more strongly marked than in L. fetidus sp. nov. Another useful diagnostic feature is the proto fold on the aperture's columellar region; it is not a fully formed fold as seen in other orthalicid genera such as Drymaeus, but it is prominent enough to distinguish $L$. fetidus sp. nov. from other Leiostracus species. Finally, the protoconch of L. fetidus sp. nov. is of a common pattern for the genus (BReure, 1979), being more similar to $L$. subtuszonatus (SALVAdor \& CAVAllari, 2013b).

Leiostracus fetidus sp. nov. stems from southern Bahia, a place already known for a high diversity of land snails (Simone, 2006) and that lately has been the source of even more new species, some presumably endemic (e.g., Salvador \& Cavallari, 2013a). Nevertheless, the terrestrial molluscan fauna of northeastern Brazil is poorly studied, as emphasized by SimONE (2012). The locality where L. fetidus sp. nov. was found is one of those small fragments of Atlantic Rainforest, close to main roads, and thus subject to much anthropic action and degradation. This fact, alongside the scarce knowledge on the local molluscan diversity, makes the description of new species from such environments an urgent necessity, for they are the first step in encouraging legal protection. Land and freshwater mollusks are deemed the most imperiled group of animals, with the highest extinction rates (LyDEARD et al., 2004; RÉGNIER et al., 2008).

Acknowledgements. We are deeply grateful to José Coltro (Femorale) for donating the material studied here and for the following people for providing us with specimens or photos of other Leiostracus species (and permission to use them): Silke Stoll (LMD), Virginie Héros (MNHN), Ronald Janssen (SMF), Valesca Lindenberg and Jeroen Goud (NCB Naturalis), Jonathan Ablett (NHMUK), and Christine Zorn (ZMB).

\section{REFERENCES}

BReURE, A. S. H. 1979. Systematics, phylogeny and zoogeography of Bulimulinae (Mollusca). Zoologische Verhandelingen 168:1-215.

Lydeard, C.; Cowie, R. H.; Ponder, W. F.; Bogan, A. E.; Bouchet, P.; Clark, S. A.; Cummings, K. S.; Frest, T. J.; Gargominy, O.; Herbert, D. G.; Hershler, R.; Perez, K. E.; Roth, B.; Seddon, M.; Strong, E. E.; Thompson, F. G. 2004. The Global Decline of Nonmarine Mollusks. BioScience 54(4):321-330.

RÉGNIER, C.; Fontaine, B.; BouChet, P. 2008. Not knowing, not recording, not listing: numerous unnoticed mollusk extinctions. Conservation Biology 23(5):1214-1221.

Salvador, R. B. \& Cavallari, D. C. 2013a. A new Oxychona species (Gastropoda: Pulmonata: Orthalicidae) from Bahia state, Brazil. Journal of Conchology 41(3):315-318.

2013b. Taxonomic revision of Leiostracus onager and Leiostracus subtuszonatus (Gastropoda: Pulmonata: Orthalicidae). Journal of Conchology 41(4):511-518.

Simone, L. R. L. 1999. Mollusca Terrestres. In: Brandão, C. R. \& CANCELLO, E. M. eds. Invertebrados Terrestres, Vol. 5, Biodiversidade do Estado de São Paulo, Brasil: Síntese do Conhecimento ao Final do Século XX. São Paulo, FAPESP, p.3-8.

2006. Land and Freshwater Mollusks of Brazil. EGB, São Paulo. 390p.

2012. Taxonomical study on a sample of pulmonates from Santa Maria da Vitória, Bahia, Brazil, with description of a new genus and four new species (Mollusca: Orthalicidae and Megalobulimidae). Papéis Avulsos de Zoologia 52(36):431-439. 